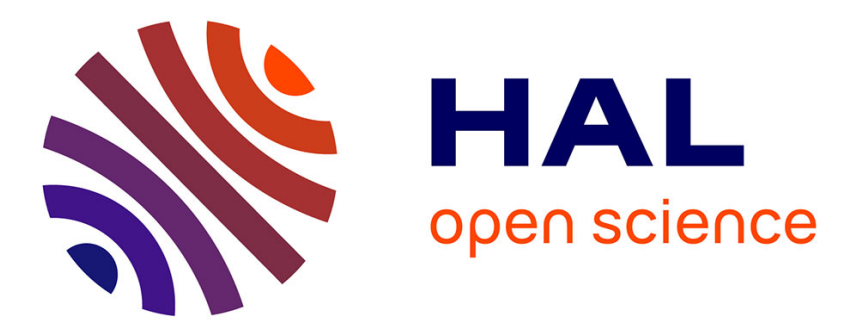

\title{
Decomposition processes under Bt (Bacillus thuringiensis) maize: Results of a multi-site experiment
} Jérôme Cortet, Mathias N Andersen, Sandra Caul, Bryan Griffiths, Richard Joffre, Bernard Lacroix, Christophe Sausse, Jacqueline Thompson, Paul Henning Krogh

\section{To cite this version:}

Jérôme Cortet, Mathias N Andersen, Sandra Caul, Bryan Griffiths, Richard Joffre, et al.. Decomposition processes under Bt (Bacillus thuringiensis) maize: Results of a multi-site experiment. Soil Biology and Biochemistry, 2006, 38 (1), pp.195-199. 10.1016/j.soilbio.2005.04.025 . hal-03218784

\section{HAL Id: hal-03218784 \\ https://hal.science/hal-03218784}

Submitted on 5 May 2021

HAL is a multi-disciplinary open access archive for the deposit and dissemination of scientific research documents, whether they are published or not. The documents may come from teaching and research institutions in France or abroad, or from public or private research centers.
L'archive ouverte pluridisciplinaire HAL, est destinée au dépôt et à la diffusion de documents scientifiques de niveau recherche, publiés ou non, émanant des établissements d'enseignement et de recherche français ou étrangers, des laboratoires publics ou privés. 


\title{
Decomposition processes under Bt (Bacillus thuringiensis) maize: Results of a multi-site experiment
}

\author{
Jérôme Cortet, Mathias N. Andersen, Sandra Caul, Bryan Griffiths, Richard Joffre, Bernard \\ Lacroix, Christophe Sausse, Jacqueline Thompson, Paul Henning Krogh
}

\author{
correspondance: jerome.cortet@univ-montp3.fr
}

\begin{abstract}
The effects of maize expressing the Bacillus thuringiensis Cry1Ab protein (Bt maize) on decomposition processes under three different European climatic conditions were assessed in the field. Farming practices using $B t$ maize were compared with conventional farming practices using near-isogenic non- $B t$ maize lines under realistic agricultural practices. The litter-bag method was used to study litter decomposition and nitrogen mineralization dynamics of wheat straw. After 4 months incubation in the field, decomposition and mineralization were mainly influenced by climatic conditions with no negative effect of the $B t$ toxin on decomposition processes.
\end{abstract}

Keywords: Wheat straw decomposition; Nitrogen mineralization; Maize; Genetically modified plants; Bacillus thuringiensis toxin

Maize (Zea mays L.) has been genetically modified to express the Cry1Ab protein from the bacterium Bacillus thuringiensis to produce a protein that is toxic to some lepidopteran insect pests, particularly the European corn borer Ostrinia nubilalis. As the toxin, released to soil from $B t$ maize in root exudates, has been shown to degrade slowly and to accumulate in soil (Tapp and Stotzky, 1995, 1998; Saxena et al., 2002; Zwahlen et al., 2003a) it is desirable to assess the effects of $B t$ maize cultivation on non-target soil organisms, similar to the assessment of any other kind of pesticide. Under laboratory conditions, no effect of the Cry1Ab protein was found on Collembola (Sims and Martin, 1997), isopods (Escher et al., 2000), protozoa, nematodes, fungi, bacteria, algae, and earthworms
(Saxena and Stotzky, 2001; Koskella and Stozky, 2002). However, a small significant effect of this toxin was noticed on soil microbial community structure (using communitylevel physiological profiles) in a high-clay soil (Blackwood and Buyer, 2004). Studies of microbial and microfaunal communities under two years of $B t$ maize revealed differences between the $B t$ and non- $B t$ crops, but non that were outside the expected variation of agricultural practices (Griffiths et al., 2005). A combination of laboratory, glasshouse and field studies (the so-called 'tiered' approach, Jepson et al., 1994) is required as the toxin can have a different behavior in the field than in the laboratory, and insecticidal activity can vary with climatic, soil texture and pH conditions (Tapp and Stotzky, 1995; Zwhalen et al., 2003b).

Other studies have examined the effects of $B t$ crops on ecosystem functions, such as decomposition. Such a functional effect could have a direct impact on soil fertility, which is important for agriculture (Eijsackers and Zehnder, 1990). Most of these studies have compared 
the decomposability of $B t$ and non- $B t$ plant residues. Hopkins and Gregorich (2003) did not observe any detectable difference in the decomposition of plant material from $B t$ and non- $B t$ maize lines, as determined by $\mathrm{CO}_{2}$ production. Flores et al. (2005) noticed a higher $\mathrm{CO}_{2}$ soil production with near-isogenic non- $B t$ maize residues than with $B t$ maize residues that could not be explained by differences in $\mathrm{C} / \mathrm{N}$ ratio, lignin maize content, or even soil microbiota. This approach is useful for determining whether there is any inherent difference in the decomposability of plant material containing the $B t$ toxin, but could not assess whether the presence of $B t$ crops would influence the decomposition of exogenous organic matter. We addressed this using a litter-bag technique. Litter-bags containing wheat straw have been suggested as a suitable field test method for assessing the effects of pesticides on decomposition processes (Kula and Römbke, 1998; Cortet et al., 2002; Knacker et al., 2003) and were recently presented as a standard test for soil functioning employed in arable fields (Römbke et al., 2002). We focus here on the effects of $B t$ maize on decomposition processes by using this litter-bag methodology under realistic agricultural conditions. The main objective was to assess the overall crop effects (i.e., $B t$ or non-Bt maize) using wheat straw (Triticum aestivum L.) as a standard exogenous material in the litter-bags.

Field locations, selected to represent diverse climatic and soil conditions, were part of the ECOGEN project (www. ecogen.dk) and also used for the analysis of soil communities (Griffiths et al., 2005). Foulum (Jutland, Denmark) was the most northerly site at $56^{\circ} 30^{\prime} \mathrm{N}, 9^{\circ} 35^{\prime} \mathrm{E}$. Varois (Bourgogne, France) was an intermediate geographic site at $47^{\circ} 34^{\prime} \mathrm{N}, 5^{\circ} 13^{\prime} \mathrm{E}$. Narbons (Midi-Pyrénées, France) was the most southerly site at $43^{\circ} 26^{\prime} \mathrm{N}, 1^{\circ} 27^{\prime} \mathrm{E}$. Soil properties are summarised in Table 1. At Foulum and Varois two maize cultivars were planted: MEB307 (a $B t$ variety producing the Cry1 Ab toxin) and Monumental (the conventional nearisogenic variety without the $B t$ trait) each randomised in plots of at least $12 \mathrm{~m} \times 19 \mathrm{~m}$ in a four-block design. Fields were ploughed in the autumn of 2002 , seeded on 22 and 28 May 2003, and harvested on 5 November and 18 October, in Foulum and Varois, respectively. All fertilization and pesticide applications were done according to current agricultural practices and were identical for the two treatments. The same protocols (with $B t$ and near-isogenic varieties) had been previously applied in 2002 on the same plots in Foulum and Varois. A similar design was used in Narbons but the maize cultivars, suited for the regional

Table 1

Soil properties of the three sites, Foulum, Varois and Narbons

\begin{tabular}{lrrllcl}
\hline & $\begin{array}{l}\text { Clay } \\
(\%)\end{array}$ & $\begin{array}{l}\text { Silt } \\
(\%)\end{array}$ & $\begin{array}{l}\text { Sand } \\
(\%)\end{array}$ & $\begin{array}{l}\text { Organic } \\
\text { matter } \\
(\%)\end{array}$ & $\begin{array}{l}\text { Calcium } \\
(\%)\end{array}$ & $\begin{array}{l}\mathrm{pH} \\
\left(\mathrm{H}_{2} \mathrm{O}\right)\end{array}$ \\
\hline Foulum & 8.7 & 24.8 & 66.5 & 6.4 & 0.0 & 6.2 \\
Varois & 43.1 & 39.0 & 17.9 & 4.8 & 18.8 & 8.1 \\
Narbons & 27.9 & 38.3 & 33.8 & 1.5 & 7.0 & 8.2 \\
\hline
\end{tabular}

climate, were DK552Bt (a Bt variety expressing the Cry1 Ab toxin) and DK532 (the conventional near-isogenic variety without the $B t$ trait). The field was ploughed and seeded on 4 June 2003 and harvested on 10 October 2003. In Narbons, the seeds of the near-isogenic maize variety were treated with Gaucho (0.112 kg/ha, active ingredient imidaclopride), whereas the $B t$ maize seeds received no insecticide. All field operations were identical for both treatments. Plots were irrigated regularly throughout the growing season at Narbons but not at Foulum and Varois. Wheat straw decomposition was assessed using litter-bag methodology (Cortet et al., 2002). The same sample of straw, hand-picked to select only internodes, was used for all three sites. It was cut into small pieces $(5-10-\mathrm{cm}$ pieces $)$, oven-dried $\left(45^{\circ} \mathrm{C}\right.$ for $48 \mathrm{~h}$ ) and $5 \mathrm{~g}$ portions sealed in $12 \mathrm{~cm} \times 12 \mathrm{~cm}$ Nylon bags (5 mm diameter mesh). Chemical analysis of five replicates of initial straw gave coefficient of variation (\%) of 0.6, 2.8 and 2.9 for $\mathrm{C}, \mathrm{N}$ and ash, respectively. Bags were installed in the field just after maize emergence and collected at regular intervals until harvest. Twenty-four bags were placed on top of the soil in the centre of each plot, within rows but between the plants. In Foulum, eight bags per plot were destructively sampled 51, 101, and 142 days after exposure. In Varois and Narbons four bags per plot were destructively sampled 43,93 , and 126 days and 43, 85, and 121 days after exposure, respectively. Wheat straw from the bags was oven-dried $\left(24 \mathrm{~h}, 45^{\circ} \mathrm{C}\right)$, sieved $(0.5 \mathrm{~mm})$ to eliminate most soil particles, weighed and ground $(1 \mathrm{~mm}$ mesh filter) with a Cyclotec-1093 mill (Tecator, Höganäs, Sweden). All samples (total of 384) were analyzed using a near-infrared spectrophotometer (NIRS system 6500, Foss Nirs systems, Inc., Silver Spring, MD, USA). Ash-free litter mass remaining (LMR), $\mathrm{N}$ concentrations and $\mathrm{C} / \mathrm{N}$ were predicted from calibrations equations derived from ash and wet chemistry measurements done on 52 representative samples (see Joffre et al., 1992; Coûteaux et al., 1998; Cortet et al., 2003 for methodological details). As litter-bags collected at a given date $(t+n)$ cannot be considered as independent from litter-bags collected at the previous date $(t)$, samples were considered as repeated measures (Grafen and Hails, 2002). LMR, $\mathrm{N}$ concentrations, and $\mathrm{C} / \mathrm{N}$ were each compared using a global two-way MANOVA (Analysis of variance with multiple variables), with sites (Foulum, Varois and Narbons) and crops (Bt/non-Bt) being fixed effect factors, and dates being the multiple variable (three sampling dates). We considered the intervals between the three sampling dates to be equivalent for each site. For each site, LMR, $\mathrm{N}$ concentration and $\mathrm{C} / \mathrm{N}$ were also each compared using a two way MANOVA, with crops $(B t /$ non- $B t)$ being fixed effects factors, blocks being a random factor, and dates being the multiple variable (three sampling dates) (Statgraphics plus 5.0 software, Manugistics Corp., Rockvile, MD, USA).

The time-course of LMR, N concentrations, and $\mathrm{C} / \mathrm{N}$ showed similar trends among the three sites (Fig. 1). There was a significant site effect (Table 2) with a greater 

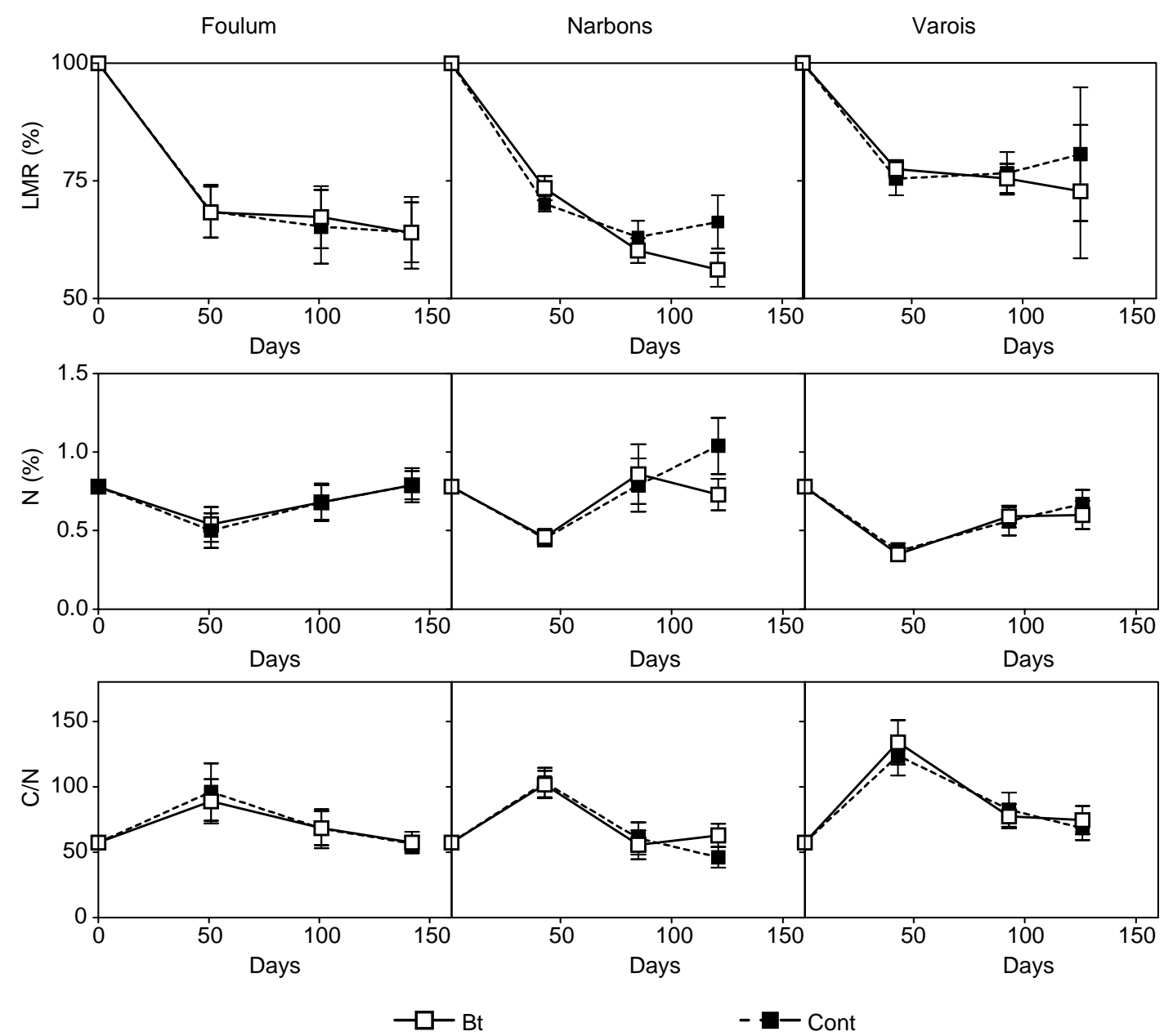

Fig. 1. Litter mass remaining, total $\mathrm{N}$ concentration and $\mathrm{C} / \mathrm{N}$ dynamics of the wheat straw (Triticum aestivum $\mathrm{L}$.) residues at the three European sites (Foulum, Varois and Narbons) under $B t$ (open symbol, solid line) and near-isogenic non- $B t$ (open symbol, dahed line) maize crops. Vertical bars indicate the standard deviation of the mean.

decomposition (opposite to LMR) at Narbons compared with Foulum and Varois, and at Foulum compared with Varois. Across all three sites, at the end of the study, decomposition was shown to be greater under $B t$ than non$B t$ maize (Table 2), although individually, the only significant effect was at Narbons (Table 3). Furthermore, the significant $B t$ effect observed in Narbons was significantly influenced by the block (Table 3 ). $\mathrm{N}$ concentrations showed the opposite trend to decomposition (non-Bt>Bt), while $\mathrm{C} / \mathrm{N}$ showed the same trend as decomposition (Fig. 1).

Our results for the three sites agreed with the common finding that straw decomposition depends strongly on climatic conditions and soil properties (Heal et al., 1997). Decomposition was faster in the warmest, irrigated Narbons site compared with the other sites. Our values of LMR agree with previous studies (e.g. Holland and Coleman, 1987; Robinson et al., 1994), indicating a slow decomposition of wheat straw due to a high initial $\mathrm{C} / \mathrm{N}$ (60 in this case) that inhibits microbial breakdown (Römbke et al., 2002). Crop effect differed significantly between sites for the three studied parameters, indicating that no general conclusions could be drawn over the effect of $B t$ maize on decomposition processes (Table 2). Single site MANOVA revealed contrasting effects (Table 3). At Narbons, significant differences were observed between straw decomposed under $B t$ maize compared with the near-isogenic non- $B t$ maize, with an increase in decomposition and $\mathrm{N}$ mineralization under DK552Bt compared with the near-isogenic DK532 cultivar at the end of the study. A possible explanation includes a variety effect, as a $B t$ containing variety could produce qualitatively different maize compared to its near-isogenic line and, thus, create a different environment for decomposers (Escher et al., 2000). This assumption was also supported by the absence of significant difference in Varois and Foulum where the other varieties, MEB307Bt and Monumental, were used. However, this result remains unclear particularly because no difference was observed concerning the microbial community structure or biomass on the same plots in Narbons (Griffiths et al., 2005). However, whether this is a variety effect or not, it can 
Table 2

Comparison of LMR (Litter mass remaining), [N] (Nitrogen concentration) and $\mathrm{C} / \mathrm{N}$ of wheat straw residues under $B t$ maize (Cry1 Ab) and corresponding nearisogenic non- $B t$ maize lines and between the sites (two-way MANOVA on 384 samples, crops and sites being the varying factors for each sampling date)

\begin{tabular}{|c|c|c|c|c|c|c|}
\hline & \multicolumn{3}{|l|}{ MANOVA } & \multicolumn{3}{|c|}{ Multiple comparison (Fisher's lsd ${ }^{\mathrm{a}}$ ) } \\
\hline & Wilk's lambda & $F$ & $P$ & Date $1^{\mathrm{b}}$ & Date $2^{\mathrm{c}}$ & Date $3^{\mathrm{d}}$ \\
\hline \multicolumn{7}{|l|}{ LMR } \\
\hline Crop $^{\mathrm{e}}$ & 0.87 & 5.6 & 0.0013 & $B t>$ iso & $n s^{\mathrm{f}}$ & Iso $>B t$ \\
\hline Site $^{g}$ & 0.33 & 27.4 & $<0.001$ & $\mathrm{~V}>\mathrm{N}>\mathrm{F}$ & $\mathrm{V}>\mathrm{F}>\mathrm{N}$ & $\mathrm{V}>\mathrm{N}, \mathrm{V}>\mathrm{F}$ \\
\hline Crop $\times$ site & 0.88 & 2.4 & 0.02 & $B t \mathrm{~N}>\mathrm{isoN}^{\mathrm{h}}$ & ns & IsoN $>B t \mathrm{~N}$ \\
\hline \multicolumn{7}{|l|}{$[\mathrm{N}]$} \\
\hline Crop & 0.76 & 12.0 & $<0.001$ & ns & ns & Iso $>B t$ \\
\hline Site & 0.31 & 36.0 & $<0.001$ & $\mathrm{~F}>\mathrm{N}>\mathrm{V}$ & $\mathrm{N}>\mathrm{F}>\mathrm{V}$ & $\mathrm{N}>\mathrm{F}>\mathrm{V}$ \\
\hline Crop $\times$ site & 0.73 & 6.4 & $<0.001$ & ns & ns & IsoN $>B t \mathrm{~N}$ \\
\hline \multicolumn{7}{|l|}{$\mathrm{C} / \mathrm{N}$} \\
\hline Crop & 0.81 & 8.7 & $<0.001$ & ns & $\mathrm{ns}$ & $B t>$ iso \\
\hline Site & 0.32 & 29.1 & $<0.001$ & $\mathrm{~V}>\mathrm{N}>\mathrm{F}$ & $\mathrm{V}>\mathrm{F}>\mathrm{N}$ & $\mathrm{V}>\mathrm{F}>\mathrm{N}$ \\
\hline Crop $\times$ site & 0.82 & 3.9 & $<0.001$ & ns & ns & $B t \mathrm{~N}>$ isoN \\
\hline
\end{tabular}

Analysis of variance with multiple variables (see text for more explanation).

a lsd, least significant difference.

${ }^{\mathrm{b}}$ Forty-three decomposition days in Varois and Narbons, 51 days in Foulum.

c 85, 93 and 101 decomposition days, respectively, in Narbons, Varois, and Foulum.

d 121, 126 and 142 decomposition days, respectively, in Narbons, Varois, and Foulum.

e Two crops: $B t$ maize (Bt) versus near-isogenic non-Bt maize (iso) (MEB 307 and Monumental in Foulum and Varois, DK532Bt and DK532 in Narbons).

${ }^{\mathrm{f}} \mathrm{ns}$, non-significant difference.

g Three sites: Foulum (F), Varois (V) and Narbons (N).

${ }^{\mathrm{h}} B t \mathrm{~N}$ and isoN, respectively, $B t$ maize in Narbons and near-isogenic non- $B t$ maize in Narbons.

Table 3

Comparison of LMR (Litter mass remaining), [N] (Nitrogen concentration), and $\mathrm{C} / \mathrm{N}$ of wheat straw residues under $B t$ maize (Cry $1 \mathrm{Ab})$ and corresponding nearisogenic $B t$ maize lines in three different sites (two-way MANOVA on 384 samples, crops and blocks being the varying factors for each sampling date)

\begin{tabular}{|c|c|c|c|c|c|c|}
\hline & \multicolumn{3}{|l|}{ MANOVA } & \multicolumn{3}{|c|}{ Multiple comparison (Fisher's 1 sd $^{\mathrm{a}}$ ) } \\
\hline & Wilk's Lambda & $\mathrm{F}$ & $\mathrm{p}$ & Date $1^{\mathrm{a}}$ & Date $2^{\mathrm{a}}$ & Date $3^{\mathrm{a}}$ \\
\hline \multicolumn{7}{|l|}{ Foulum } \\
\hline \multicolumn{7}{|l|}{ LMR } \\
\hline Crop $^{a}$ & 0.99 & 0.01 & 0.99 & ns & ns & $\mathrm{ns}$ \\
\hline Block $^{\mathrm{b}}$ & 0.40 & 0.13 & 0.99 & ns & ns & ns \\
\hline Crop $\times$ block $^{\mathrm{c}}$ & 0.71 & 2.1 & 0.03 & $\mathrm{~ns}^{\mathrm{a}}$ & $\mathrm{ns}$ & Iso $2>B t 2, B t 3>$ iso 3 \\
\hline$[\mathrm{N}]$ & \multicolumn{6}{|c|}{ No significant differences } \\
\hline $\mathrm{C} / \mathrm{N}$ & \multicolumn{6}{|c|}{ No significant differences } \\
\hline \multicolumn{7}{|l|}{ Varois } \\
\hline LMR & \multicolumn{6}{|c|}{ No significant differences } \\
\hline$[\mathrm{N}]$ & \multicolumn{6}{|c|}{ No significant differences } \\
\hline $\mathrm{C} / \mathrm{N}$ & \multicolumn{6}{|c|}{ No significant differences } \\
\hline \multicolumn{7}{|l|}{ Narbons } \\
\hline \multicolumn{7}{|l|}{ LMR } \\
\hline Crop & 0.09 & 3.52 & 0.36 & ns & ns & Iso $>B t$ \\
\hline Block & 0.38 & 0.14 & 0.99 & ns & $\mathrm{ns}$ & ns \\
\hline $\begin{array}{l}\text { Crop } \times \text { block } \\
{[N]}\end{array}$ & 0.17 & 5.1 & $<0.001$ & $B t 2>$ iso 2 & $\mathrm{~ns}$ & $\mathrm{~ns}$ \\
\hline Crop & 0.25 & 1.01 & 0.59 & $\mathrm{~ns}$ & ns & Iso $>B t$ \\
\hline Block & 0.56 & 0.08 & 0.99 & ns & ns & ns \\
\hline Crop $\times$ block & 0.20 & 4.2 & $<0.001$ & $B t 4>$ iso 4 & $B t 3>$ iso 3 & Iso $3>B t 3$, iso $4>B t 4$ \\
\hline \multicolumn{7}{|l|}{$\mathrm{C} / \mathrm{N}$} \\
\hline Crop & 0.26 & 0.96 & 0.61 & $\mathrm{~ns}$ & ns & ns \\
\hline Block & 0.57 & 0.07 & 0.99 & $\mathrm{~ns}$ & $\mathrm{~ns}$ & $\mathrm{~ns}$ \\
\hline Crop $\times$ block & 0.23 & 3.9 & 0.001 & Iso $4>B t 4$ & $\mathrm{~ns}$ & $B t 3>$ iso $3, B t 4>$ iso 4 \\
\hline
\end{tabular}

\footnotetext{
a See Table 1.
}

${ }^{\mathrm{b}}$ Four blocks numbered from 1 to 4.

' Iso2, iso3, iso4 are, respectively, near-isogenic non- $B t$ maize for the Blocks 2 to $4 . B t 2, B t 3, B t 4$ are, respectively, $B t$ maize for the Blocks 2 to 4. 
be concluded that under the cropping systems studied $B t$ maize had no negative effect on the decomposition of exogenous organic matter.

\section{Acknowledgements}

These studies were supported by the EU-funded project, ECOGEN QLK5-CT-2002-01666 (www.ecogen.dk). Thanks to Christiane Lovy (Université de FrancheComté), Céline Caillol (Université Aix-Marseille III), Alain Brasseur (ARVALIS, Baziège), Jean-Louis Lucas and Stéphane Grippon (CETIOM, Dijon), and Lars Andreasen (DIAS, Foulum) for their technical assistance during the project. The Scottish Crop Research Institute receives grant-in-aid from the Scottish Executive Environment and Rural Affairs Department.

\section{References}

Blackwood, C.B., Buyer, J.S., 2004. Soil microbial communities associated with $B t$ and non-Bt corn in three soils. Journal of Environmental Quality 33, 832-836.

Cortet, J., Poinsot-Balaguer, N., Gillon, D., Joffre, R., Ourcival, J.-M., 2002. Effects of pesticides on microarthropods and organic matter recycling in a maize field: use and discussion of the litter-bag methodology. European Journal of Soil Biology 38, 261-265.

Cortet, J., Joffre, R., Elmholt, S., Krogh, P-H., 2003. Increasing species and trophic diversity of mesofauna affects fungal biomass, mesofauna community structure and organic matter decomposition processes. Biology and Fertility of Soils 37, 302-312.

Coûteaux, M.M., McTiernan, K.B., Berg, B., Szuberla, D., Dardenne, P., Bottner, P., 1998. Chemical composition and carbon mineralization potential of Scots pine needles at different stages of decomposition. Soil Biology \& Biochemistry 30, 583-595.

Eijsackers, H., Zehnder, A.J., 1990. Litter decomposition: a Russian matriochka doll. Biogeochemistry 11, 153-174.

Escher, N., Käch, B., Nentwig, W., 2000. Decomposition of transgenic Bacillus thuringiensis maize by microorganisms and woodlice Porcellio scaber (Crustacea: Isopoda). Basic and Applied Ecology 1, 161-169.

Flores, S., Saxena, D., Stotzky, G., 2005. Transgenic Bt plants decompose less in soil than non-Bt plants. Soil Biology \& Biochemistry 37, 10731082.

Grafen, A., Hails, R., 2002. Modern Statistics for the Life Sciences, Learn How to Analyse Your Experiments. Oxford University Press, New York p. 351.

Griffiths, B.S., Caul, S., Thompson, J., Birch, A.N.E, Scrimgeour, C., Andersen, M.N., Cortet, J., Messéan, A., Sausse, C., Lacroix, B., Krogh, P.H., 2005. A comparison of soil microbial community structure, protozoa and nematodes in field plots of conventional and genetically modified maize expressing the Bacillus thuringiensis CryIAb toxin. Plant and Soil, in press.
Heal, O.W., Anderson, J.M., Swift, M.J., 1997. Plant litter quality and decomposition: an historical overview. In: Cadisch, G., Giller, K.E. (Eds.), Driven by Nature. Plant Litter Quality and Decomposition. CAB International, Wallingford, UK, pp. 3-30.

Holland, E.A., Coleman, D.C., 1987. Litter placement effects on microbial and organic matter dynamics in an agroecosystem. Ecology 68, 425-433.

Hopkins, D.W., Gregorich, E.G., 2003. Detection and decay of the Bt endotoxin in soil from a field trial with genetically modified maize. European Journal of Soil Science 54, 793-800.

Jepson, P.C., Croft, B.A., Pratt, G.E., 1994. Test systems to determine the ecological risks posed by toxin release from Bacillus thuringiensis genes in crop plants. Molecular Ecology 3, 81-89.

Joffre, R., Gillon, D., Dardenne, P., Agneessens, R., Biston, R., 1992. The use of near-infrared reflectance spectroscopy in litter decomposition studies. Annales des Sciences Forestières 49, 481-488.

Knacker, T., Förster, B., Römbke, J., Frampton, G., 2003. Methods for assessing the effects of pesticides on organic matter breakdown. Soil Biology \& Biochemistry 35, 1269-1287.

Koskella, J., Stozky, G., 2002. Larvicidal toxins from Bacillus thuringiensis subspp, kurstaki, morrisoni (strain tenebrionis), and israelensis have no microbicidal or microbiostatic activity against selected bacteria, fungi, and algae in vitro. Canadian Journal of Microbiology 48, 262-267.

Kula, C., Römbke, J., 1998. Testing organic matter decomposition within risk assessment of plant protection products. Environmental Science Pollution Research 5, 55-60.

Robinson, C.H., Dighton, J., Frankland, J.C., Roberts, J.D., 1994. Fungal communities on decaying wheat straw of different resource qualities. Soil Biology \& Biochemistry 26, 1053-1058.

Römbke, J., Heimbach, F., Hoy, S., Kula, C., Scott-Fordsmand, J., Sousa, P., Stephenson, G., Weeks, J., 2002. Effects of Plant Protection Products on Functional Endpoints in Soil (EPFES): Lisbon, 24-26 April 2002. SETAC Press, Pensacola FL, USA p. 109.

Saxena, D., Stotzky, G., 2001. Bacillus thuringiensis (Bt) toxin released from root exudates and biomass of $B t$ corn has no apparent effect on earthworms, nematodes, protozoa, bacteria, and fungi in soil. Soil Biology \& Biochemistry 33, 1225-1230

Saxena, D., Flores, S., Stozky, G., 2002. Bt toxin is released in root exudates from 12 transgenic corn hybrids representing three transformation events. Soil Biology \& Biochemistry 34, 133-137.

Sims, S.R., Martin, J.W., 1997. Effects of the Bacillus thuringiensis insecticidal proteins $\operatorname{Cry} 1 \mathrm{~A}(\mathrm{~b}), \operatorname{Cry} 1 \mathrm{~A}(\mathrm{c})$, CryIIA and CryIIIA on Folsomia candida and Xenylla grisea (Insecta: Collembola). Pedobiologia 41, 412-416.

Tapp, H., Stotzky, G., 1995. Insectidal activity of the toxins Bacillus thuringiensis subspecies kurstaki and tenebrionis adsorbed and bound on pure and soil clays. Applied and Environmental Microbiology 61, 1786-1790

Tapp, H., Stotzky, G., 1998. Persistence of the insecticidal toxin from Bacillus thuringiensis subsp, Kurstaki in soil. Soil Biology \& Biochemistry 30, 471-476.

Zwahlen, C., Hilbeck, A., Gugerli, P., Nentwig, W., 2003a. Degradation of the Cry $1 \mathrm{Ab}$ protein within transgenic Bacillus thuringiensis corn tissue in the field. Molecular Ecology 3, 765-775.

Zwhalen, C., Hilbeck, A., Howald, R., Nentwig, W., 2003b. Effects of transgenic Bt corn litter on the earthworm Lumbricus terrestris. Molecular Ecology 12, 1077-1086. 